\title{
Notau - the Hanseatic harbour at Avaldsnes, south-west Norway: written sources, maps and place-names
}

\author{
FRODE FYLLINGSNES
}

Fyllingsnes, F. 2019. Notau - the Hanseatic harbour at Avaldsnes, south-west Norway: written sources, maps and placenames. AmS-Skrifter 27, 209-216, Stavanger, ISSN 0800-0816, ISBN 978-82-7760-183-0.

Written sources, mostly of German origin from the fifteenth century, mention Notau, a Hanseatic harbour somewhere in the south-western part of Norway. Ships from towns, including Lübeck, Danzig and Kampen, called here. Dutch maps from the sixteenth and seventeenth centuries show that Notau was situated on the island of Karmøy in Rogaland county. The placename 'Nottå' has been used in modern times for locations at two islands belonging to the royal farm of Avaldsnes. Most probably one of these islands was called 'Nautøy' in the medieval period, becoming Notau in German. The written sources indicate that the Germans built houses in Notau, where the merchants are likely to have traded with the inhabitants of the region.

Frode Fyllingsnes, Midtre Suldalsgate 12, N-4014 STAVANGER, NORWAY. E-mail: frode.fyllingsnes@lyse.net

Keywords: Hanse, medieval harbour, maritime maps, trade, piracy, Karmøy

Research into the Hanse's presence in Norway has concentrated on its activity in the towns of Bergen, Oslo and Tønsberg, and its dominance in foreign trade. ${ }^{1}$ Little is known about the relations between Hanseatic merchants and Norwegians in non-urban areas. In order to get to and from Bergen, the ships followed the sea route close to the coast of western Norway. These are rough waters where big vessels still take advantage of sheltering islands where they can be found. In medieval times it was common for seamen to pause in good harbours at night. Thus, there must have been some contact between people on board Hanseatic ships and inhabitants of the small coastal settlements where people lived by combining farming and fishing.

Written sources, maps and place-names, examined while writing a book about the medieval history of the island of Karmøy in the northern part of Rogaland county all suggested a Hanseatic presence in the Avaldsnes area. ${ }^{2}$ At the same time in the late 1990s the marine archaeologist, Endre Elvestad from Stavanger Maritime Museum started his investigations of the harbour area at Avaldsnes. The historical and archaeological work combined to become a very interesting interdisciplinary project. This article provides a short introduction to Karmsundet and Avaldsnes, and then presents the written documents, old maps and place-names related to the place called Notau (otherwise 'Notoy', 'Nothau', 'Notaw', 'Natouw', 'Notow', 'Notouwe', 'Nothowe', 'Nothow', 'Notoir', 'Note' and 'Notu').

\section{Karmsundet and Avaldsnes}

Avaldsnes is situated on the north-east of Karmøy facing Karmsundet, the sea 'highway' leading to Bergen (Fig. 1). Karmsundet, separating Karmøy from the mainland, is probably the most strategic place along the Norwegian coast. Those who in prehistoric and medieval times controlled this long, narrow sound where almost all ship traffic passed also automatically played an important political, economic and military role in western Scandinavia. Large burial mounds with rich finds from the Bronze Age and Iron Age in the Avaldsnes area, where the sound is at its narrowest, suggest that mighty kings and chieftains knew to take advantage of their power already in prehistoric time. ${ }^{3}$ One of the legendary kings was Augvald, who according to local tradition gave his name to the place. Two members of the Avaldsnes elite were buried in ship graves. The Storhaug and Grønhaug ship burials date from the second half of the eighth century and are thus older than their more famous counterparts in Vestfold, East Norway (Oseberg and Gokstad). After 


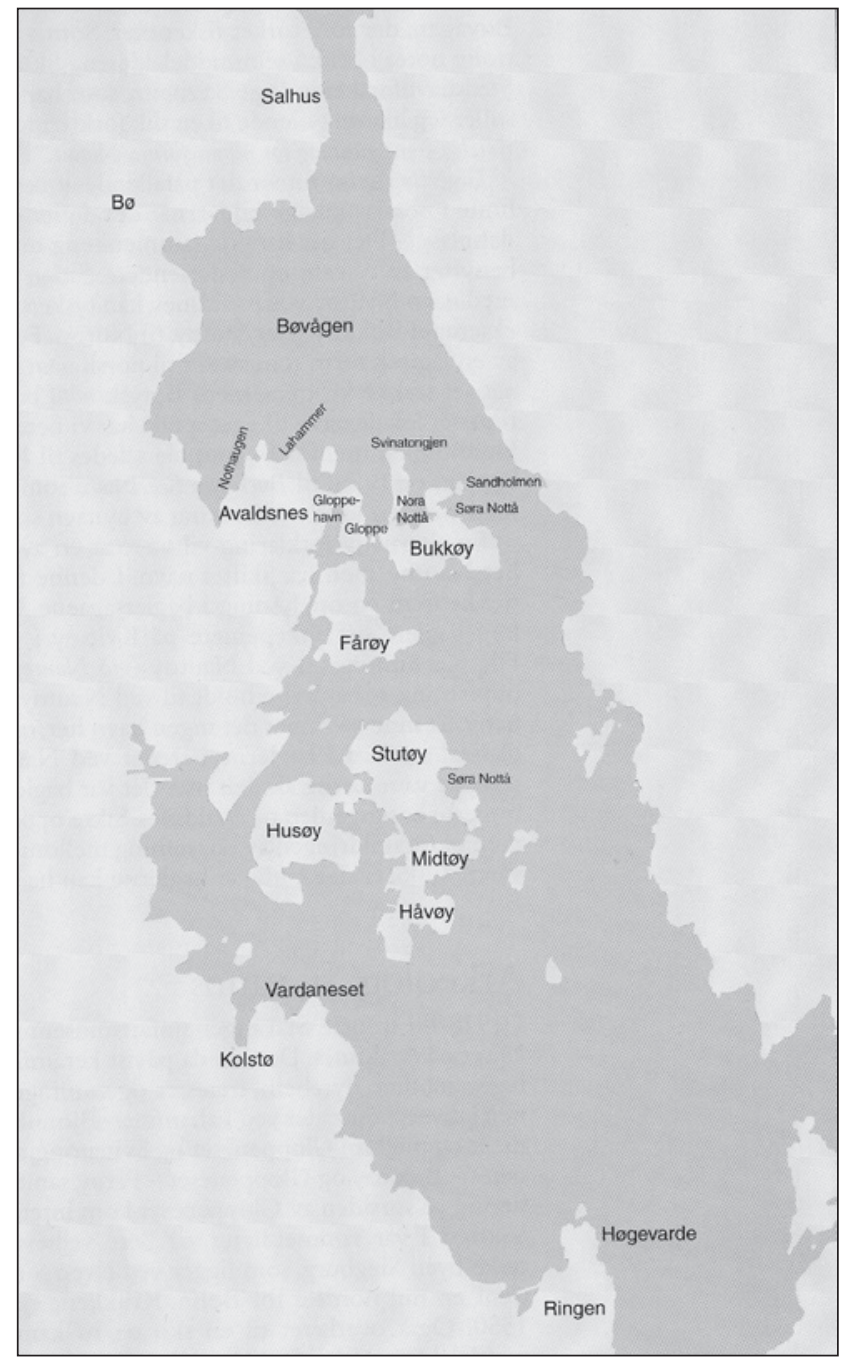

Fig. 1. Karmsundet between the island of Karmøy to the left and the mainland to the right. The ship traffic along the Norwegian coast in medieval times passed through this narrow sound. The Hanseatic harbour Notau was situated somewhere in the Avaldsnes area (illustration: Torstein Breivik, Karmøy municipality and Ingund Svendsen, AM/UiS).

the Battle of Hafrsfjord around 872, King Harald Hårfagre (Fairhair) lived at his royal farms in western Norway, Avaldsnes being one of them and probably the most important. Later, other kings also stayed here from time to time. In the second half of the thirteenth century the church of St. Olav was erected at Avaldsnes on the orders of King Håkon Håkonsson who died in 1263.

The church of St. Olav at Avaldsnes was closely associated with royal power. ${ }^{4}$ From the beginning of the fourteenth century it was one of the four most important royal free chapels, partly separated from papal authority. The clergy here played a role in the administration of the region and served as scribes on the king's visits. The church was granted a number of farms that were formerly royal land, which enabled the prelates to engage in trade. 'Avaldsnesbussen', the ship belonging to the church, is recorded in English toll registers of the early fourteenth century. ${ }^{5}$ Archaeological investigations at Avaldsnes carried out by the University of Oslo in 2011 and 2012 revealed among other things the remnants of a big stone building close to the church. ${ }^{6}$ This building from around 1300 has been interpreted as the king's residence. Norwegian parallels are only to be found in the towns of Bergen, Oslo and Tønsberg.

In the late Middle Ages, when Norway had joint kings with Sweden and Denmark, Avaldsnes and the church of St. Olav became less significant to royal authority. The farm here became the home of the local vicar from around 1400. In 1368, during the war between Denmark-Norway and the Hanse, the Germans burnt down the royal farm of Avaldsnes and also other farms along Karmsundet. ${ }^{7}$ In the following century the merchants of the Hanse were to carry out more peaceful activities at Avaldsnes.

\section{Notau in written sources}

Johan van deme Berne was a member of the 'Bergenfahrer' guild in Lübeck. In his will dated 29th November 1425 he gave several gifts to ecclesiastical institutions in Bergen. One bequest in his will reads: 'Item to Notow geve ik 2 tunnen teres to dem nuwe' ('To Notau I give two barrels of tar for the buildings'). ${ }^{8}$ Nothing is said about the location of Notau, implying that it was a place wellknown to the Lübeck merchants of the period.

When Notau is mentioned in other written sources, it is often in connection with dramatic events involving ships and crew, particular wreck and piracy. It is said in a letter from the merchants of Danzig presented during negotiations between the Hanse and Denmark in September 1434 that Gerd van Telgeten's ship had been wrecked in Notau in 1430. ${ }^{9}$ His goods were rescued, but some of them confiscated by the king's bailiff. Another complaint states that Peder Oxe in Notau took a ship and goods from the merchant Radeke Lange worth 500 gulden. Oxe was a Danish nobleman who supported King Erik of Pomerania, who at that time licensed sailors to capture Hanseatic ships. 'Private' pirates, as well as those with letters of marque, were feared and the narrow Karmsundet provided an ideal place for their activities.

The next reference to Notau is in the copy-book belonging to Heinrich Kalteisen from Koblenz, who in 1452 was appointed by the Pope as archbishop of Nidaros (now Trondheim) in mid-Norway. ${ }^{10}$ After various intrigues he had to resign in October the next year following a meeting with King Christian I in Bergen. Subsequently, they 
both sailed south along the coast. In Notau Kalteisen's ship caught up with the king and there Kalteisen gave a speech and new negotiations followed in which the prelate offered to travel to Rome to give up his position. While these talks were going on, the ships with the king, the former archbishop and their advisers lay side by side in Notau. The king and his council agreed to let Kalteisen go to Rome, but the latter obviously spent some time in Notau before the journey started. This is apparent because Kalteisen's copy-book also contains a letter of indulgence to the nobleman Henrik Krummedike and his wife, dated Notau on the 26th November 1453. ${ }^{11}$

In June 1454 two English cargo ships with linen cloth arrived in Notau. The Kontor in Bergen organized an expedition to seize the ships, a reaction that must be seen in light of the English capture of eight Hanseatic ships off the Danish coast in spring 1454. What then happened in Notau is somewhat unclear, but it seems that the English were warned and left before the Hanseatic ships arrived. These events are mentioned in a chronicle written by Johann Bulder, secretary of the Kontor in Bergen. ${ }^{12}$ The men who assisted the English were two prominent Norwegians, the commander of Bergenhus castle, Olav Nilsson, and the Bergen bishop, Torleiv Olavsson. Olav Nilsson was an eager opponent of the Hanseatic dominance in Bergen. An alternative interpretation of the incident in Notau is that Olav Nilsson freed the English from Hanseatic captivity. ${ }^{13}$

A letter of complaint from the Kontor in Bergen to the king, Christian I, probably written in 1455 , deals with the misdeeds of Olav Nilsson. ${ }^{14}$ The story of the two English ships coming to Notau is repeated. When Olav returned to Bergen in 1455, after a spell as commander of Älvsborg castle in Sweden, the Hanseatic merchants rioted and Olav had to seek safety in a monastery. The building was burnt down and both Olav, his young son and his brother, Peder Nilsson, died. Subsequently, the merchants plundered Olav's estates in western Norway. Olav's widow, Elise Eskilsdatter, and their remaining children (Olav, Axel and Magdalena) swore revenge and started a private vendetta against the Hanse that lasted throughout the fifteenth century. According to the chronicle written by Christian Gerens, secretary of the Kontor in Bergen, in 1469 Olav Olavsson captured a ship from Hamburg outside Skudenes, the southern tip of Karmøy. ${ }^{15}$ This information is somewhat strange, since another source records that this Olav had previously drowned in $1465 .{ }^{16}$ Perhaps it was his younger brother, Axel, who captured the German ship. Gerens writes that the Hanse in 1469 arrested Axel Olavsson in Notau. Axel promised to meet before the king and answer for his actions. ${ }^{17}$
An account book belonging to the guild of the Bergen merchants in Lübeck records in 1471 that 'unde de copman buten bleff wynterlaghe to Nothow' (merchants had wintered in Notau), probably in $1470 / 71 .^{18}$ A sum of money is mentioned from the sale of beer. We also know that during the stay it was forbidden to sell beer after 10 $\mathrm{pm}$. Nothing is said about the number of ships and men involved, but normally between two and six ships sailed together to Bergen..$^{19}$ It implies that around 1470 Notau must still have provided an infrastructure allowing many Germans to spend the winter there.

In June 1476 merchants of Deventer, Kampen and Zwolle sent a letter with many complaints to the Kontor in Bergen. ${ }^{20}$ One particular point was a protest against the treatment received by merchants coming to Notau: 'Item oick dat men mogheliken gheyne bothe offen neme, die van anxtes wegen uytweken to Notoir off andreswoir voir die sterfte' (Also that one should possibly not receive boats which have sidestepped to Notau or elsewhere because of fear of death). It is not easy to understand what had happened, but it seems that Dutch merchants escaping from dramatic dangers at sea were treated poorly in Notau. A letter from the merchants of Kampen to the Kontor written in 1477 also refers to these events. ${ }^{21}$ It said that the merchants had arrived in Notau naked and barefooted and there each had to pay 25 gulden, probably for food and new clothes.

A protocol of debt from Lübeck dated 1499 refers to an incident in Notau in 1487, when a ship belonging to Gerd Scroder sunk. ${ }^{22}$ Some of the cargo was rescued and this later caused an argument among the persons involved.

In 1532 the Danish-Norwegian nobleman Nils Lykke sent a letter to Eske Bille, commander at Bergenhus. ${ }^{23}$ Lykke was probably staying at this time at Hesby on Finnøy, an administrative centre in south-west Norway. In the letter Lykke asked for permission to take over some fish, probably part of the royal revenue, and send it with a tradesman who soon would go to Notau, where a ship from Danzig was waiting.

\section{Notau in historic and topographic literature}

Knowledge of Notau and its location gradually faded, but the place did not fall into total oblivion. Notau was mentioned in 'Den norske So' written in Bergen at the end of the sixteenth century. Though the author is unknown, he was probably of German origin. It records that the Hanseatic Kontor in Norway was once situated 'zu Nothaw', but it had moved to Bergen because of pirates. ${ }^{24}$ Towards the end of the seventeenth century Edvard Edvardsen re- 


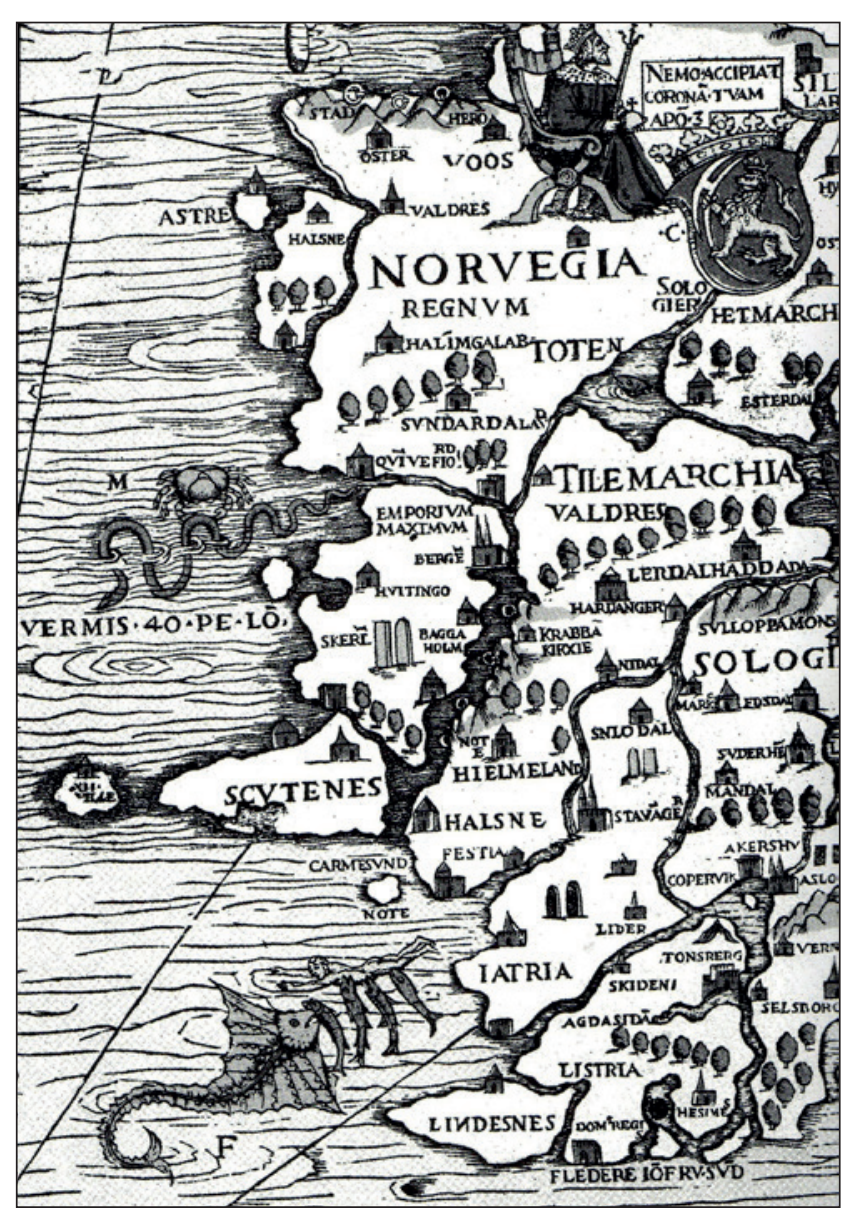

Fig. 2. A part of Carta Marina from 1539 with the south-western part of Norway. The map is very inaccurate, but it is interesting to notice that the place-name 'Note' occurs twice close to the island of 'Scvtenes' (Karmøy) (Nasjonalbiblioteket, Oslo).

peated this in his book about Bergen and added that Notau had been in Karmsund. ${ }^{25}$ Several later writers considered that Notau, in fact, had to be sought on the small island of Nautøy in the Boknafjord to the east of Karmøy. Bendix Christian de Fine in his description of Rogaland from 1745 wrote about dilapidated, but still visible walls at Nautøy. ${ }^{26}$ Jens Kraft in his topographic work about Rogaland from 1829 stated without any doubt that Notau had been located at Nautøy in the Boknafjord. ${ }^{27}$ His colleague, Boye Strøm, was a bit less categorical in 1888, suggesting that Nautøy 'måske' (perhaps) was identical with 'Nothaw' referred to in 'Den norske So'. ${ }^{28}$

The discussion about the location of Notau briefly intensified around 1930. The local historian, Anton Espeland started the debate by publishing several articles where he took for granted that Notau had been at Nautøy in the Boknafjord. ${ }^{29}$ This led to an investigation by Rogaland historielag (the Historical Association of Rogaland), obviously after some pressure from persons in the Karmsund area. The members of the board visited
Nautøy on 2nd July 1930, but they did not find anything to indicate that this small island had once been a Hanseatic stronghold. It had no natural harbour and the position of the island was well away from the sea lane along the coast. The board's report concluded that Notau could not have been situated on Nautøy in the Boknafjord. ${ }^{30}$ Instead, it said, one ought to look closer at the islands in Karmsundet, close to Avaldsnes. Among those who argued for this position were the senior rector, Ludvig Solheim and teacher, Aamund Salveson. Their opinion was shared by the secondary school teacher, Olav Brattegard who had studied the German archives in order to seek information about the Hanse in Bergen. ${ }^{31}$ Here, he also came across the name Notau and realized that it must have been an important place for the Hanseatic merchants.

The local historians in Rogaland do not seem to have been aware of the book already published by the German Friedrich Bruns in 1900, Die Lübecker Bergenfahrer und Ihre Chronistik. Bruns placed Notau on Karmøy, where 'at the eastern side of the elongated island Karmøy lay once the hamlet of Notau, ornated with a church, which is frequently mentioned in hanseatic sources'. ${ }^{32} \mathrm{He}$ thought Notau had been at Høyevarde south of Avaldsnes, a well-known harbour. However, in order to reach a more definitive answer, it is necessary to look at old maps and place-names.

\section{Notau on maps}

Notau appears on several maps from the sixteenth and seventeenth centuries. ${ }^{33}$ The oldest is Carta Marina from 1539 by Olaus Magnus, the exiled Swedish archbishop living in Rome (Fig. 2). On his map the name 'Note' is given at two places: there is an island called 'Note' to the south of 'Carmesvnd' (Karmsundet), and the same name also occurs close to 'Hielmeland' in the inner parts of Rogaland. The map is, of course, very inaccurate, but it is interesting to note the inclusion of Notau together with other important and well-known places.

Maps improved a great deal towards the end of the sixteenth century, mostly thanks to Dutch cartographers who were busy plotting coasts and sea routes as the Netherlands rose to commercial leadership in early modern Europe. The pioneer was Lucas Janszoon Waghenaer who produced Spieghel der Zeevaerdt, the world's first sea atlas, published in Leiden in 1584-85. It did not show the coast of south-west Norway, but the coastline from Bergen to Jæren was given in the new edition from 1588. In the north-western part of Karmøy is the place named 'Notuwe' (Fig. 3). Waghenaer published a new sea 


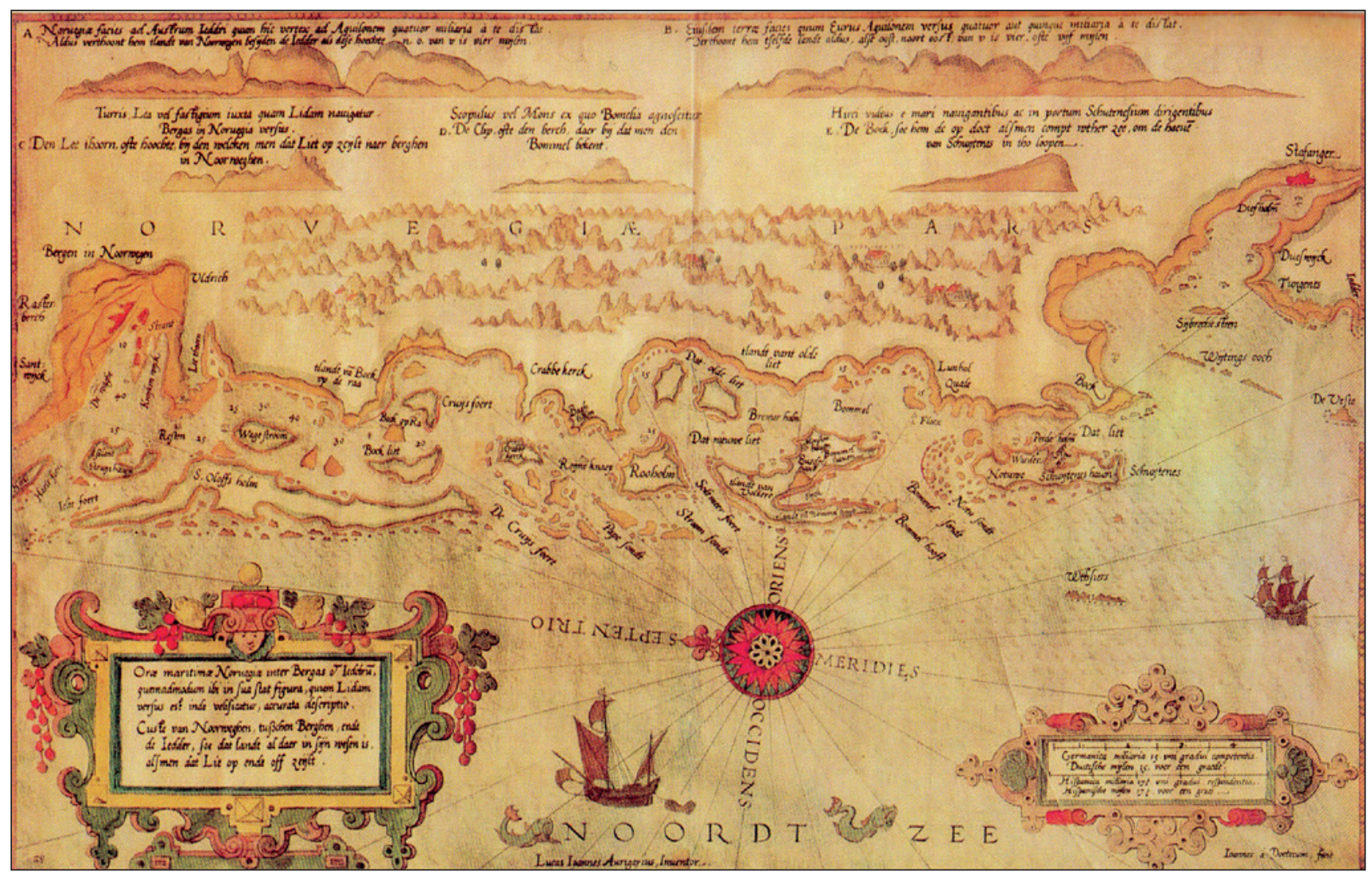

Fig. 3. The cartography improved greatly during the sixteenth century. This map showing the coast between Jaren and Bergen is from the 1588 edition of Lucas Janszoon Waghenaer's Spieghel der Zeevaerdt. The name 'Notuwe' is placed on the northern part of the island of Karmøy (Nasjonalbiblioteket, Oslo).

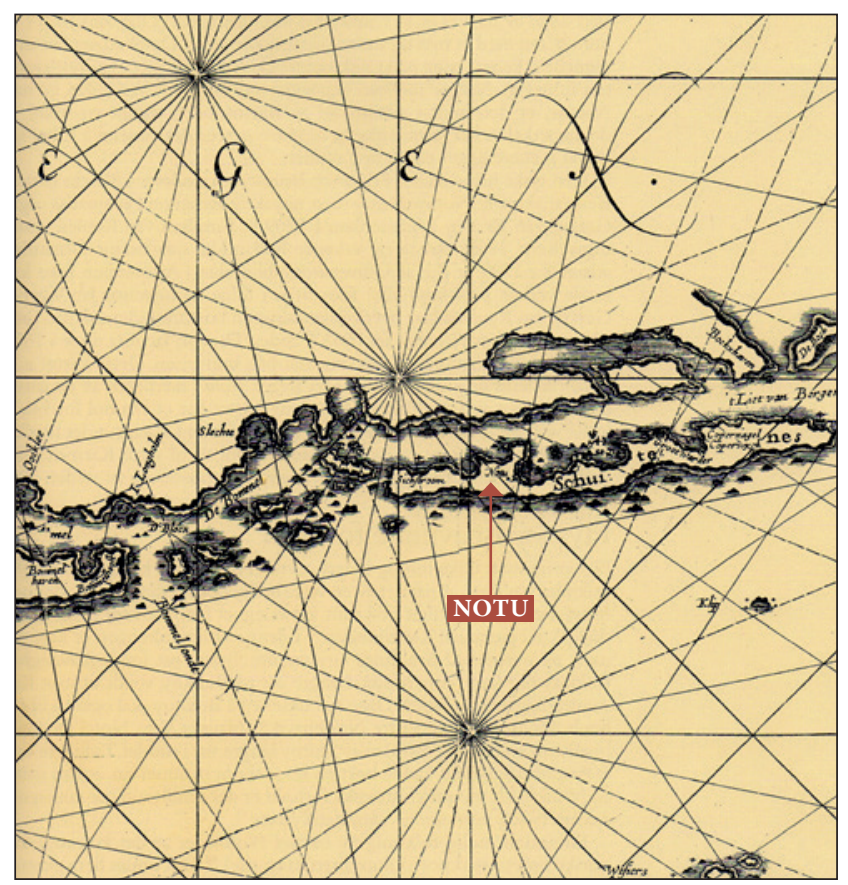

Fig. 4. A part of the map from 1663 made by the Dutchman Theunis Jacobsz. By an east-facing bay close to Avaldsnes is the place called 'Notu' (Universiteitsbibliotheek van Amsterdam, Kaartenzel 34-15-15). Notu marked with an arrow. atlas in 1592, Thresoor der Zeevaert, with the same location for 'Notuwe'.

The next great Dutch cartographer was Willem Janszoon Blaeu and in his sea atlas from 1608, Het Licht der Zeevaert, 'Notuwe' is located as on Waghenaer's 1588 map. Close to the name is a symbol marking a building, probably the church of St. Olav at Avaldsnes. On another map from 1627 made by Blaeu and Johannes Janssonius, 'Notuwe' is shown in the same location as the 1603 map, but close to the name there appears a circle with a dot inside, marking the place. ${ }^{34}$ The building next to it is likely to be St. Olav's church.

Janssonius later joined Blaeu's strongest competitor, the House of Hondenius. In a French edition of one of their atlases from 1647 Janssonius published a map showing the three southernmost of the Norwegian bishoprics. Notau is not marked here, but the text accompanying the map states that on Karmøy there are 'diverse villages' and one of them is 'Notu'.

The German historian, Friedrich Bruns wrote that Notau was located almost exactly as marked in a sea atlas published by Gerhard van Keulen in Amsterdam in $1709 .{ }^{35}$ The van Keulen family was famous for their voluminous and beautiful atlases. The University Library in 
Amsterdam could not in 1998 provide a copy of the map showing south-west Norway because of its poor preservation, but according to curator, Jan Werner it is almost identical with a map made by Theunis Jacobsz and published in 1663. Jacobsz died in 1650, so it was probably his sons who produced it. On Jacobsz' map the name 'Notu' is placed by an east-oriented bay in the Avaldsnes region (Fig. 4). Near it is a symbol probably showing the church. Unfortunately, the islands in Karmsundet are not marked, at least not as islands, but perhaps attached to Karmøy itself. The Dutch sea maps thus show that Notau was to be found on the north-east of Karmøy, in the Avaldsnes area, but they do not give the exact location. For that we turn to local place-names.

\section{The place name Notau}

The name 'Nottå' occurs on two islands in Karmsundet close to Avaldsnes (see Fig. 1). On Bukkøy we find both 'Nora Nottå' (North Nottå) and 'Søra Nottå' (South Nottå). The same places are also known as 'Vestre' and 'Austre Nottehamn' (Western and Eastern Nottehamn). In addition, the name 'Søra Nottå' has been used for a small bay on Stutøy further south. These names are not in common use today, although early in the twentieth century the local historian, Aamund Salveson heard a wife say about her husband, that he 'natta yve på Nottå', meaning he stayed at Nottå during the night. ${ }^{36}$ In a court case from 1767 a fishing ground in Karmsundet close to Avaldsnes is called 'Notte'. ${ }^{37}$

It is very likely that these rare and rather peculiar place-names, all with the stem not-, should be seen in connection with Notau mentioned in written medieval sources. Several possible explanations of the origin of the name Notau have been put forward: ${ }^{38}$

a) One suggestion is that it derives from the Norwegian word 'natt' (night), locally pronounced /nót/, and referring to a harbour where ships stayed during the night.

b) The Norwegian word 'nott' meaning 'small height' has also been mentioned. There are examples from Rogaland where this word has been used to form place-names, but the topography on the islands in Karmsundet does not support that in the case here.

c) The name Notau seldom occurs in Norwegian sources from the late Middle Ages. This may indicate that the name first and foremost was used by German and later Dutch merchants and cartographers. They may have translated a local island name, for instance Bukkøy or Stutøy, to Notau. Norwegian 'bukk' means 'billy-goat', whereas 'stut' is 'a bull'. The first component, 'not', may be derived from Old High German 'nôz' or Old Frisian 'nât', meaning cattle. The second component, 'ow', would then be Norwegian 'øy' (island). There are some examples of such germanification of Norwegian place-names along the coast route leading to Bergen. Hestholmen ('hest' is horse in Norwegian) north of Kopervik on Karmøy thus turned into 'Perde holm' ('perd' is horse in Low German) and the island name Bokn became 'Buck van See'.

d) One of the islands in Karmsundet close to Avaldsnes was named Nautøy (meaning 'island where cattle graze') in the Middle Ages, but later changed name. The islands of Bukkøy or Fårøy are the most likely candidates, but Stutøy and Husøy further south cannot be ruled out. As already mentioned the name Nottå is found on Bukkøy. The first component in the name Fårøy is normally seen in connection with the tree-name, pine ('furu' in Norwegian), but pollen diagrams from Husøy show that on this island there has not grown much pine and the deforestation caused by burning is apparent in the Bronze Age. ${ }^{39}$ It is thus suggested that the Danish word denoting 'sheep', 'får', is a more likely origin. In the Early Modern period there were Danish vicars at Avaldsnes, who undoubtedly had animals grazing on the islands in the sound. Fårøy may thus be a pretty recent name, whereas the island's medieval name is unknown.

Inge Særheim, who has studied the name Notau, argues in favour of a name change (above) and that is accepted here. This may be supported by the Saga of the Baglars. In 1208, during the Norwegian civil wars, the two main parties, 'Birkebeinar' and 'Baglar' negotiated on Kvitsøy, an island south of Karmøy. While this happened, the Baglar fleet was stationed 'við Nauteyna'. ${ }^{40}$ Historians have assumed that 'Nauteyna' is Nautøy in the Boknafjord. But it would have been difficult to keep a fleet by this small island without a harbour and a settlement to provide provisions. The statement in the saga makes much more sense if it refers to an island named Nautøy in Karmsundet. It is quite possible, but not certain, that the Baglars were in control of Avaldsnes at that time, which makes such a theory more plausible. So it is proposed that Bukkøy, or perhaps Fårøy, was named 'Nautøy' in medieval times, and that the Hanseatic merchants established themselves here and adopted the name.

\section{Harbour and trading-place?}

Notau was obviously an important Hanseatic harbour. Several of the documents referred to above, for instance the quoted one from 1476, suggest that during most of the fifteenth century the place was controlled by the Kontor in Bergen. It is very likely that the Hanseatic merchants in Notau traded with local people living in the region. The 
authorities did not want trade to take place outside the towns, but this was very difficult to control in a country with such a long coastline and many fjords. The DanishNorwegian kings of the fifteenth century, spending most of their time in Copenhagen, issued laws and decrees stating that the Hanseatic merchants should stay away from rural areas. ${ }^{41}$ Since such prohibitions were repeatedly issued, it shows of course that trade between Norwegians living in the countryside and merchants from the Hanse was quite common. The king's representatives were too few and far between to control what went on of Notau and the activities there are further discussed in the papers in this volume by Geir Atle Ersland and by Endre Elvestad and Arnfrid Opedal. It is necessary here only to draw attention to a document from around 1440. It is a witness letter from a lost copy-book written in Latin that belonged to the bishop of Bergen. ${ }^{42}$ Two men named Svein Bøs and Anders Dan swore under oath that some of the servants of the bishop had been forced away from a royal free harbour ('libero portu Regio'), so they nearly lost both ship and cargo. The name and location of this harbour is not given. In 1444 Bøs and Dan again appeared as witnesses in Bergen, this time in a court case dealing with a ship from Rouen, which Olav Nilsson had arrested in Karmsundet. ${ }^{43}$ The testimonies show that they were present when the arrest took place. It is thus possible that Dan and Bøs had some sort of official duties in the region. If there was an international harbour in south-western Norway in the 1440s where merchants could trade without breaking the regulations that restricted such activity to the towns, it would be strange if it was not situated in Karmsundet.

The ship traffic along the Norwegian coast normally passed through the sound, making it a very strategic place. Here merchant vessels could find safe anchorage. It was a rather densely populated district and good agricultural land, especially in the northern half of Karmøy, meant that the farmers could provide visiting tradesmen with food. Rich herring and cod fisheries took place along this part of the coast, and in the fjords in Ryfylke to the east there were forests of oak and pine trees stretching down to the sea. That the Hanse choose to establish Notau at Avaldsnes as their stronghold in south-western Norway, is thus not surprising.

\section{Endnotes}

${ }^{1}$ See for instance Helle 1982; Helle 1990; Nedkvitne 1983; Nedkvitne 1990; Nedkvitne 1994.

${ }^{2}$ Fyllingsnes 2000.

${ }^{3}$ Hernæs 1997; Nordenborg Myhre 1998; Opedal 1998; Opedal 2010.

${ }^{4}$ Helle 1999; Fyllingsnes 2000.
${ }^{5}$ DN XIX, nos 422 and 436.

${ }^{6}$ Skre 2012.

${ }^{7}$ NGL II, 1, no. 347 (\$S 7-8, 27-28, 34); HR II, no. 4; DN

XIX, no. 583 (extract); RN VII, no. 46.

${ }^{8}$ Die Lübecker Bergenfahrer und Ihre Chronistik, 56f. 'Item to Notow geve ik 2 tunnen teres to dem Buwe'.

${ }^{9}$ HR II, 1, no. 381 (complaints 39 and 62).

${ }^{10}$ Henrik Kalteisens Kopibog, 154, $163 f$.

${ }^{11}$ Ibid., 209; NGL II, 2, no. 236.

${ }^{12}$ Die Lübecker Bergenfahrer und Ihre Chronistik, 384.

13 Bjørkvik 1997, 255.

${ }^{14}$ HR II, 4, no. 349 (\$ 4); DN XVI, no. 291.

${ }^{15}$ Die Lübecker Bergenfahrer und Ihre Chronistik, 358.

16 Koht 1949, 404.

17 Die Lübecker Bergenfahrer und Ihre Chronistik, 357.

18 Ibid., 242.

19 Bjørsvik 1996, 23.

${ }^{20}$ HR II, 7, no. 343 (\$ 10); NGL II, 2, no. 6.

${ }^{21} H R$ II, 7, no. 416; NGL II, 2, no. 434.

${ }^{22}$ Die Lübecker Bergenfahrer und Ihre Chronistik, 194.

${ }^{23}$ DN XXII, no. 212.

${ }^{24}$ Den norske So 1584, 22; see Geir Atle Ersland, this volume, for further discussion.

${ }_{25}$ Edvardsen 1951, 377.

${ }^{26}$ de Fine 1987, 117.

27 Kraft 1829, 230.

28 Strøm 1888, 334.

29 Espeland 1926; Espeland 1928; Espeland 1930.

30 Solheim 1931.

${ }^{31}$ Brattegard 1942.

32 'An der Ostseite der langgestreckten Insel Karmø lag ehemals die öfters in hansischen Quellen genannte, durch eine Kirche gezierte Ortschaft Notau [...].' Die Lübecker Bergenfahrer und Ihre Chronistik, xcviii-ic.

${ }^{33}$ Fyllingsnes 2000, 306-310; Fyllingsnes 2001a; Fyllingsnes 2001b; Fyllingsnes 2004.

${ }^{34}$ I would like to thank Professor Ove Tobias Gudmestad, University of Stavanger, who made me aware of this map and also the map in the French atlas of 1647.

35 Die Lübecker Bergenfahrer und Ihre Chronistik, ic.

36 Solheim 1931, 38.

37 Tingbok Ryfylke, vol. C 2 (1766-1770), 80b.

38 Særheim 1998; Særheim 1999; Særheim 2000; Særheim 2006; Særheim 2009; Fyllingsnes 2000, 310-312; Fyllingsnes 2004.

39 Lindblom et al. 1997.

40 Soga om birkebeinar og baglar, 116.

${ }^{41}$ Fyllingsnes 2004, 15.

${ }^{42}$ DN XVI, no. 131.

${ }^{43}$ DN XVIII, no. 63.

\section{References}

Unpublished documents

Tingbok Ryfylke, vol. C 2 (1766-1770). Statsarkivet i Stavanger.

Printed sources (see also list of abbreviations)

Henrik Kalteisens Kopibog, ed. by A. Bugge. Christiania: Aktieselskabet Thronsen \& Co.s Bogtrykkeri, 1899.

Die Lübecker Bergenfahrer und Ihre Chronistik, by F. Bruns. Berlin: Pass und Garleb, 1900. 
Den norske So 1584, Norske magasin. Skrifte angaaende Norge og forfattede efter Reformationen vol. II, 1-120. Christiania: Johan Dahls Forlag, 1869.

Soga om birkebeinar og baglar, vol. 2, ed. by H. Magerøy. Oslo: Solum forlag, 1988.

\section{Secondary literature}

Bjørkvik, H. 1997. Finnøy. Gard og cett, vol. 3: Gardane på Fogn, Talgje og Fisterøyane. Finnøy: Finnøy kommune.

Bjørsvik, E. 1996. Hanseatene og Norden. Bergen: Bryggens Museum.

Brattegard, O. 1942. Eit gamalt sjøfartssentrum i Karmsund. Historisk tidsskrift, 265-266.

Edvardsen, E. 1951 [1694]. Bergen. Første part. Bergen: Bergens historiske forening.

Espeland, A. 1926. Rogaland i millomalderen. Aarshefte Rogalands historielag 12, 43-49.

Espeland, A. 1928. Bokn og Nautøy. Frå Rogalands eldste handelshistorie. Aarshefte Rogalands historielag 14, 4-8.

Espeland, A. 1930. Buck van See - Buck van Raa. Maal og minne, 110-112.

de Fine, B.C. 1987 [1745]. Stavanger Amptes udførlige Beskrivelse. Stavanger: Dreyer.

Fyllingsnes, F. 2000. Karmøys historie, vol. II: Middelalderen. Stavanger: Dreyer.

Fyllingsnes, F. 2001a. Havn og handel i skriftlige kilder, kart og stedsnavn, in E. Elvestad and A. Opedal (eds), Maritim-arkeologiske forundersøkelser av middelalderhavna på Avaldsnes, Karmøy, 19-24. Arkeologisk museum Stavanger rapport 18. Stavanger: Stavanger sjøfartsmuseum og Arkeologisk museum.

Fyllingsnes, F. 2001b. Appendix 1. Katalog over skriftlige kilder og kart, in E. Elvestad and A. Opedal (eds), Maritim-arkeologiske forundersøkelser av middelalderhavna på Avaldsnes, Karmøy, 90-98. Arkeologisk museum Stavanger rapport 18. Stavanger: Stavanger sjøfartsmuseum og Arkeologisk museum.

Fyllingsnes, F. 2004. Notow - hanseatane si hamn på Avaldsnes. Heimen 41(1), 3-21.

Helle, K. 1982. Bergen bys historie, vol. I: Kongesete og kjøpstad. Bergen: Universitetsforlaget.

Helle, K. 1990. Die Historiographie der nationalhistorischen Hanseforschung in Norwegen, in Die Hanse in Nordeuropa: Handel - Politik - Kultur. Synthesekonzepte in der Geschichtsschreibung, Bericht über das 4. Deutsch-Norwegische Historikertreffen in Berlin, Mai 1989, 89-100. Oslo: Norges Allmennvitenskapelige Forskningsråd.

Helle, K. 1999. Olavskirken 1250-1350 - sognekirke og kongelig kapell, in S. I. Langhelle and B. Lindanger (eds), Kongskyrkje ved Nordvegen. Olavskyrkja på Avaldsnes 750 år, 54-103. Aksdal: Lokalhistorisk stiftelse.

Hernæs, P. 1997. Karmøys historie, vol. I: Fra istid til 1050. Stavanger: Dreyer.

Koht, H. 1949. Olav Nilsson, in Norsk biografisk leksikon vol. 10, 399-405. Oslo: Aschehoug.
Kraft, J. 1829. Det Vestenfieldske Norge topographiskstatistisk beskrevet. Oslo: Grøndahl.

Lindblom, I., Simonsen, A. and Solheim, L. 1997. Husøy - paleoecology and prehistory of a small island on the SW coast of Norway. Stavanger: Arkeologisk Museum i Stavanger.

Nedkvitne, A. 1983. Utenrikshandelen fra det vestafjeldske Norge 1100-1600. Unpublished PhD thesis, University of Bergen.

Nedkvitne, A. 1990. The Hansa in Norway as seen by Norwegian historians today, in Die Hanse in Nordeuropa: Handel - Politik - Kultur. Synthesekonzepte in der Geschichtsschreibung, 89-100. Bericht über das 4. Deutsch-Norwegische Historikertreffen in Berlin, Mai 1989. Oslo: Norges Allmennvitenskapelige Forskningsråd.

Nedkvitne, A. 1994. How important was Hansa trade for the Norwegian economy, in V. Henn and A. Nedkvitne (eds), Norwegen und die Hanse. Wirtschaftliche und kulturelle Aspekte im europäischen Vergleich, 9-30. Frankfurt am Main: Peter Lang.

Nordenborg Myhre, L. 1998. Historier fra en annen virkelighet. Fortellinger om bronsealderen ved Karmsundet. Stavanger: Arkeologisk Museum i Stavanger.

Opedal, A. 1998. De glemte skipsgravene. Makt og myter på Avaldsnes. Stavanger: Arkeologisk Museum i Stavanger.

Opedal, A. 2010. Kongemakt og kongerike. Gravritualer og Avaldsnes-områdets politiske rolle 600-1000. Oslo: Unipub.

Skre, D. 2012. Utgravningene på Avaldsnes avsluttet. Frá haug ok heiðni 4, 3-9.

Solheim, L. 1931. Bokn og Nautøy. Årshefte Rogalands historielag 17, 36-39.

Strøm, B. 1888. Topografisk-statistisk Beskrivelse over Stavanger Amt. Kristiania: Aschehoug.

Særheim, I. 1998. 'Notau...udi Karmsund'. Hansaens første handelsfaktori i Noreg?, in G. Akselberg and J. Bondevik (eds), Ord etter ord. Heidersskrift til Oddvar Nes, 242-54. Bergen: Norsk bokreidingslag.

Særheim, I. 1999. Språkkontakt i seinmellomalderen bakgrunn for lokale namn og namneformer. Frá haug ok heiðni 2, 28-33.

Særheim, I. 2000. Notau - innfallsport for hansaen i Noreg? in Karmøy kommune (ed.), Havn og handel $i$ 1000 år. Karmøyseminaret 1997, 110-116. Stavanger: Dreyer.

Særheim, I. 2006. 'Notau...udi Karmsund'. Toponyms from southwestern Norway reflecting language contact in medieval times, in E. Brylla and M. Wahlberg (eds), Proceedings of the 21st International Congress of Onomastic Sciences 2002, 2, 289-302. Uppsala: Institutet för språk och folkminnen.

Særheim, I. 2009. Lågtysk påverknad på sørvestnorske stadnamn i seinmellomalderen, in L. Mattfolk and T. Ainiala (eds), Namn och kulturella kontakter, NORNArapporter 85, 29-39. Uppsala: Norna förlaget. 